\title{
Dry matter yield, nutritive value and tiller density of tall fescue and perennial ryegrass swards under grazing
}

\author{
S.J. HENDRIKS ${ }^{1}$, D.J. DONAGHY ${ }^{1}$, C. MATTHEW ${ }^{2}$, M.R. BRETHERTON ${ }^{2}$, \\ N.W. SNEDDON ${ }^{1}$, G.P. COSGROVE ${ }^{3}$, C.L. CHRISTENSEN ${ }^{2}$, S. KAUFONONGA ${ }^{1}$, \\ J. HOWES ${ }^{2}$, M.A. OSBORNE ${ }^{2}$, P.S. TAYLOR ${ }^{3}$ and M.J. HEDLEY ${ }^{2}$ \\ ${ }^{1}$ Institute of Veterinary, Animal and Biomedical Sciences, Massey University, \\ Private Bag 11222, Palmerston North, New Zealand \\ ${ }^{2}$ Institute of Agriculture and Environment, Massey University, \\ Private Bag 11222, Palmerston North, New Zealand \\ ${ }^{3}$ AgResearch Ltd, Grasslands Research Centre, Tennent Drive, Palmerston North 4442, New Zealand \\ s.hendriks@massey.ac.nz
}

\begin{abstract}
Alternative pasture species with the potential to supply quality forage during summer feed shortages, such as tall fescue (TF), are of interest to dairy farmers. A paddockscale study was undertaken to compare performance of $\mathrm{TF}$ managed on a shorter rotation similar to perennial ryegrass (RG) (TF-RG) with TF managed on a longer rotation more consistent with its morphology of 4 live leaves/tiller (TF-TF), and with RG (RG-RG). Accumulated dry matter (DM) yields were similar for the three treatments. Patch grazing was observed during the first spring, with more long patches in TFTF than in either TF-RG or RG-RG. Sown-species leaf area index (LAI) was greater in TF-TF compared with TF-RG and RG-RG $(2.25,1.56$ and 0.90 , respectively; $\mathrm{P}<0.05$ ). The proportions of grass weeds were higher in the TF-RG $(\mathrm{P}<0.05)$ compared with TF-TF and RG-RG treatments $(302,207$ and $164 \mathrm{~g} / \mathrm{kg} \mathrm{DM}$, respectively). A soil fertility gradient with distance along the paddock away from the farm race was recorded, with Olsen $\mathrm{P}$ declining at $0.130 \mathrm{mg} / \mathrm{kg} / \mathrm{m}$ with distance from the farm race. Tiller density, LAI and yield of sown species and total yield sampled were all positively correlated with Olsen P. Overall, this study highlights the importance of managing $\mathrm{TF}$ pastures according to its specific growth habits. However, attaining longer grazing rotations under field conditions whilst trying to maintain cow intakes, is likely to continue to prove elusive.
\end{abstract}

Keywords: perennial ryegrass (Lolium perenne), tall fescue (Festuca arundinacea), grazing management

\section{Introduction}

New Zealand's pastoral industries rely predominantly on a mixture of perennial ryegrass (RG; Lolium perenne L.) and white clover (Trifolium repens L.) (Kemp et al. 2002). However, moisture and temperature stress during summer and autumn in certain areas result in low dry matter (DM) yields, decreased herbage quality and reduced animal performance (Litherland et al. 2002), resulting in continuing interest in the use of alternative permanent pasture species. Tall fescue (TF; Festuca arundinacea Schreb., syn., Schedonorus arundinaceus and Lolium arundinaceum) is a perennial grass with potential to out-yield RG and supply quality forage during dry and hot summer and autumn periods (McCallum et al. 1992). The development of suitable TF cultivars has increased its use in pastoral agriculture (Easton \& Pennell 1993), however, for maximum growth, TF should be managed differently from RG due to morphological differences between the two species (Fulkerson \& Donaghy 2001; Donaghy et al. 2008). Tall fescue maintains 4 live leaves/tiller, compared to 3 in RG. Typically, during a dry summer and autumn, $\mathrm{TF}$ exhibits a faster regrowth rate resulting in $20-40 \%$ more DM yield and higher quality herbage than slowergrowing RG (Lazenby \& Lovett 1975; McCallum et al. 1992; Clark et al. 2010). Milne et al. (1997) recommend faster grazing rotations for TF compared to $\mathrm{RG}$, ranging from 5 days faster from October-December to 20-25 days faster from May-September. Kerrisk \& Thomson (1990) reported an optimal rotation for TF during spring of 15 days compared to 30 days for RG. However, as TF produces longer and thicker leaves which have a slower elongation rate and a longer lifespan than those of RG (Kemp et al. 2001), faster grazing rotations may jeopardise production and persistence (Donaghy et al. 2008).

This provides a quandary for the management of TF on-farm; grazing rotations need to be frequent enough to maintain herbage quality, yet not so frequent that they jeopardise yield and persistence. It has been reported (e.g., Easton et al. 1994; Milne et al. 1997) that farmers have been disappointed with TF persistence and performance, limiting its use on dairy farms. Such dissatisfaction with TF may arise, at least in part, from farmers inadvertently assuming TF can be managed according to the criteria used for RG. Therefore, a paddock-scale study was undertaken to compare performance of TF managed on a shorter 
rotation similar to $\mathrm{RG}$, and TF managed on a longer rotation more consistent with its morphology of 4 live leaves/tiller.

\section{Methods}

\section{Site}

This study (January 2013 to December 2015) was on the Massey University Dairy 4 farm, $5 \mathrm{~km}$ south of Palmerston North $\left(40.397431^{\circ} \mathrm{S}, 175.624011^{\circ} \mathrm{E}\right)$, on a Tokomaru silt loam. Soil $\mathrm{pH}$ and nutrient contents (75 mm depth) before sowing were: $\mathrm{pH} 5.8$, Olsen phosphorus (P) $40 \mathrm{mg} / \mathrm{L}$, sulphur (S) $7.5 \mathrm{mg} /$ $\mathrm{kg}$, potassium $(\mathrm{K}) 0.20 \mathrm{me} / 100 \mathrm{~g}$, calcium $(\mathrm{Ca}) 7.3$ $\mathrm{me} / 100 \mathrm{~g}$, magnesium $(\mathrm{Mg}) 1.0 \mathrm{me} / 100 \mathrm{~g}$ and sodium (Na) $0.08 \mathrm{me} / 100 \mathrm{~g}$. The mean annual rainfall at the site over 3 years was $869 \mathrm{~mm}, 10 \%$ less than the 30 year average of $970 \mathrm{~mm}$. The experimental site $(2.25$ ha) was sprayed with $2 \mathrm{~L} /$ ha Roundup ${ }^{\circledR}$ Transorb ${ }^{\circledR}$ (540 g/L a.i. glyphosate) before mouldboard ploughing, power and Dutch harrowing. This area was split into three approximately equal-sized grazing strips and sown on 16 November 2012 with a vee-ring roller-drill followed by light chain harrows to cover the seed. One strip was sown with RG (cv. Bealey; $28 \mathrm{~kg} / \mathrm{ha}$ ) and white clover (cv. Kopu II and Tribute, each sown at 2 $\mathrm{kg} / \mathrm{ha}$ ), and the other two strips with TF (cv. Easton; 25 $\mathrm{kg} / \mathrm{ha}$ ) and white clover (cv. Kopu II and Tribute, each sown at $2 \mathrm{~kg} / \mathrm{ha})$. Cropmaster $15(15.2 \%$ nitrogen $(\mathrm{N})$, $10 \% \mathrm{P}, 10 \% \mathrm{~K}$ and $7.7 \% \mathrm{~S}$ ) was applied at $200 \mathrm{~kg} / \mathrm{ha}$ on 15 November 2012.

\section{Experimental design}

The three strips were each subjected to different unreplicated species/grazing treatments to observe sward performance under dairy cow grazing. The RG strip (RG-RG, 33 × $257 \mathrm{~m}, 0.85 \mathrm{ha}$ ), and one TF strip (TF$\mathrm{RG}, 29 \times 255 \mathrm{~m}, 0.74 \mathrm{ha}$ ) were rotationally grazed when 2-3 RG leaves/tiller were fully emerged or earlier if canopy closure occurred (targeting above $3000 \mathrm{~kg}$ DM/ha) (Fulkerson \& Donaghy 2001). The RG-RG and TF-RG strips were adjacent to each other. The second TF strip (TF-TF, $29 \times 253 \mathrm{~m}, 0.73 \mathrm{ha}$ ) was rotationally grazed when 2-4 TF leaves/tiller were fully emerged or earlier if canopy closure occurred (Donaghy et al. 2008). The more frequent rotations were for periods of higher growth rates. All grazing events employed an average of 130 cows to achieve a post-grazing residual of close to $5 \mathrm{~cm}$ within 2 days.

During the experiment secondary hypotheses were developed in response to evolving sward phenomena. A pattern of heavily and lightly grazed patches was visually obvious on TF-RG and TF-TF strips, hence sward height data were analysed to quantify typical sward height distributions of the three strips midexperiment. Secondly, in collecting data on tiller density at the end of the experiment, an assumed decreasing soil fertility gradient with distance from the entry gates on the farm race to the far end of the three strips was utilised, to test a hypothesis that tiller density was influenced by the fertility gradient during the experiment.

\section{Herbage production and defoliation}

The first grazing of all three strips was based on strong establishment of seedlings and before shading reduced tiller appearance and pasture quality. Subsequent grazings were as outlined above. During the experiment, the average leaf appearance interval of RG ranged from 10-11 days in spring (October-December), 11-15 days in summer (January-March), and 18-20 days in autumn/ winter (April-September), compared to TF at 11-12, 11-15 and 14-15 days, respectively. The dates of all grazing events are presented in Figure 1.

A rising plate meter (RPM) was used to record all pre- and post-grazing masses until October 2013 (100 readings/strip taken pre- and post-grazing); RPM readings were calibrated for $\mathrm{TF}$ and $\mathrm{RG}$ against cut quadrats. No difference between species was found and so a single calibration equation was used where pasture mass ( $\mathrm{kg} \mathrm{DM} / \mathrm{ha}$ ) equals the average reading from RPM x $140+500$ (DairyNZ 2008). From 1 October 2013 pre- and post-grazing masses were measured using an electronic C-Dax pasture meter (King et al. 2010) and calibration equation determined from mown yields. Total DM yield for each grazing was calculated as the difference between pre- and post-grazing masses (DM yield equals current pre-grazing herbage mass minus post-grazing herbage mass from the previous grazing).

\section{Herbage nutritive value}

The day before grazing, herbage samples were collected to assess grass species nutritive value. A sample of approximately $10 \times 10 \mathrm{~cm}$ was cut ( $5 \mathrm{~cm}$ stubble) using a shearing hand-piece, from approximately 20 sites randomly located along each of the three strips. These subsamples were bulked for each grazing strip. Other species were removed from the bulk sample and the grass-only portion stored in a freezer at $-20^{\circ} \mathrm{C}$. Samples were then freeze-dried, ground to pass a $1 \mathrm{~mm}$ sieve and analysed by near-infrared reflectance spectroscopy (FeedTECH; AgResearch Grasslands, Palmerston North) to determine crude protein (CP), soluble sugars and starch (SSS), neutral detergent fibre (NDF), lipid and ash, organic matter digestibility (OMD) and metabolisable energy (ME) contents.

Patch grazing of the TF was visually apparent after the first four grazings, so at each grazing from 9 July 2013 until 5 March 2014, herbage (at least 20 subsamples, 5 cm stubble) were collected from 'long' or 'short' areas and analysed separately. Long and short areas were 


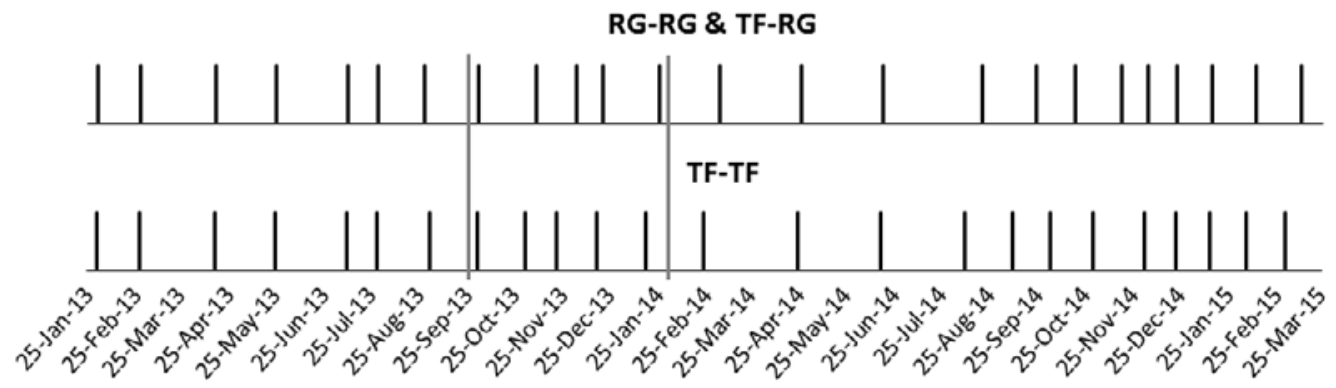

Figure 1 Grazing dates (vertical bars) of perennial ryegrass (RG-RG), tall fescue grazed as for ryegrass (TF-RG) and tall fescue grazed as for tall fescue (TF-TF) strips. Grey vertical lines denote the period from which the nutritive values and pasture heights have been evaluated.

categorised visually and probably represent a cycle of rejection of herbage around dung patches (Valentine 2000), with greater accumulation and morphological development in the following regrowth interval and further rejection at the subsequent grazing (Hirata 2000). This stratified sampling was discontinued from March 2014 because mowing was introduced on two occasions to control post-grazing residuals to around 5 $\mathrm{cm}$ height, reducing the incidence of patch grazing.

Tiller density, sown species leaf area and soil fertility The strips were sampled for tiller density at the conclusion of the experiment (14 December 2015). Before sampling, the three strips were visually observed to have a gradient of decreasing fertility moving from the entry gate at the farm race $(0 \mathrm{~m})$ to the back of the strip $(\sim 250 \mathrm{~m})$. To allow assessment of fertility effects on persistence by regression analysis, 4 transects running across each strip were identified at $55,100,145$ and $190 \mathrm{~m}$ from the farm race and 12 herbage samples $(76 \times 117 \mathrm{~mm})$ cut to ground level on each transect, totalling 48 samples/strip. For each herbage sample, the number of tillers of sown and nonsown grass species were counted. Tiller density (tillers/ $\mathrm{m}^{2}$ ) was calculated as tillers counted divided by the area sampled $\left(\mathrm{m}^{2}\right)$. The sample was further separated into sown grass leaf lamina and pseudostem, other grasses, clover, weeds and dead herbage to determine botanical composition. For each strip, a subsample of sown grass leaf material was retained and length and width of leaf lamina segments in the sample measured, before drying and weighing to provide a specific leaf area $\left(\mathrm{cm}^{2} / \mathrm{g}\right.$ dry weight) for multiplication with leaf mass per unit area for the 48 samples/strip to estimate sown species leaf area index (LAI). Subsamples were oven-dried for at least $48 \mathrm{~h}$ at $70^{\circ} \mathrm{C}$ and component dry weights recorded. Sown species leaf lamina samples for the four positions in each strip were sent to Hills Laboratories (Hamilton, New Zealand) for herbage nutritive value analyses as described above, and herbage $\mathrm{N} \%$ determination. After cutting each herbage sample, a $25 \mathrm{~mm}$ diameter soil core to $75 \mathrm{~mm}$ depth was collected from the bared earth and the cores from each transect pooled to provide 12 soil samples for quantifying the perceived soil fertility gradients in each strip. Soil samples were sent to Hills Laboratories for a standard soil analysis, including Olsen P.

\section{Statistical analysis}

Nutritive values were analysed using a general linear model in SAS 9.3 (SAS Institute Inc., Cary, NC, USA, 2012). The model included the fixed effects of pasture height (long versus short patches), treatment (RG-RG, TF-RG, TF-TF), height by treatment interaction, date of sampling as a covariate and the random repeated effect of strip, as strips were randomly assigned to treatments at the start of the trial and there are repeat measurements by strip of different orders. Variables (number of sown tillers, tiller density, sown species yield, total yield, LAI of sown species, and proportions of sown species, sown lamina, sown pseudostem, other grasses, weeds and dead matter) were analysed using a general linear model in SAS 9.3 with the fixed effect of treatment, transect, and the treatment by transect interaction; this allowed for testing to see if the strips were different, based on data from transects. It is emphasised that because the RG-RG, TF-RG and TFTF treatments were unreplicated, except for subsamples within strips, results of statistical analyses do not test for differences between the treatments, but for differences between the treatment strips, which potentially may be affected by other factors besides sown species, such as soil gradients. To evaluate the relationship between soil fertility and sward variables (tiller density, sown species LAI and yield, and total yield), a multiple linear regression model of tiller density on Olsen $\mathrm{P}$ was analysed in Minitab ${ }^{\mathrm{TM}}$ version 10.51 (Minitab 10.51 Extra Statistical Software 1995, www.minitab.com), such that the regression intercept would estimate RG tiller density at high fertility with additional terms for the RG-RG:TF-RG and RG-RG:TF-TF tiller density difference, and loss of tiller density (assumed constant 
for the three strips) per unit decline in soil Olsen P. In addition, the perceived soil fertility gradient was evaluated by regression of soil test parameters with distance along the paddock strips from the race.

\section{Results and Discussion}

In practice the rotation length for the TF-TF strip did not maintain the plants near the 4 leaf stage; high growth rates compromising herbage quality at high canopy levels (e.g., >2800 kg DM/ha; Milne et al. 1997) meant that management decisions erred on the side of caution and the TF-TF strip was grazed at an average of 2.5 leaves/tiller, similar to the RG-RG strip. However, differences in leaf appearance rate between $\mathrm{TF}$ and RG meant that the TF-TF strip was grazed up to 5 days faster in January-March, up to 9 days slower in AprilJune, up to 6 days faster from September-November, and up to 16 days slower in December (post-seeding) than the TF-RG and RG-RG strips.

\section{Herbage dry matter yields}

Accumulated DM yield over 3 years for the three treatments is presented in Figure 2. From the first grazing in January 2013 until June 2013, accumulated $\mathrm{DM}$ yields were 6088, 5023 and $4969 \mathrm{~kg} \mathrm{DM} / \mathrm{ha}$ for RG-RG, TF-RG and TF-TF, respectively. These results mirror those of Clark et al. (2010) where a RG-white clover sward yielded $40 \%$ more DM than a TF-white clover sward from establishment (January) through the winter of Year 1, due to the slow establishment of TF. In the second growth period (July 2013-June 2014) accumulated DM yields were 12 648, 12133 and $13616 \mathrm{~kg} \mathrm{DM} / \mathrm{ha}$ for the RG-RG, TF-RG and TF-TF, respectively. In the third growth period (July 2014-March 2015) comparable data were 7685, 8519 and $8814 \mathrm{~kg} \mathrm{DM} / \mathrm{ha}$. In an un-replicated trial, Rollo et al. (1998) found that TF consistently out-yielded $\mathrm{RG}$ in the first 2 years after establishment, with the largest advantage at sites associated with moderate water deficits (around $161 \mathrm{~mm}$; water deficit equals rainfall minus potential evapotranspiration) compared with those that did not experience deficit (either fully irrigated, or with higher water deficits (up to $235 \mathrm{~mm}$ )). In the current study, accumulated DM yields were only greater for the TF-TF strip in Year 1.

In summer (December-February 2013/2014) of Year 2, accumulated DM yields were 2179,2527 and $3108 \mathrm{~kg}$ $\mathrm{DM} /$ ha for the RG-RG, TF-RG and TF-TF, respectively, and in the summer (December-February 2014/2015) of Year 3, comparable data were 2542, 2812 and $2578 \mathrm{~kg}$ DM/ha. Allo \& Southon (1967) reported that TF outyielded RG due to greater persistence and tolerance of drier conditions, since TF has greater water-use efficiency and deeper root penetration allowing it to extract moisture from a greater soil depth compared

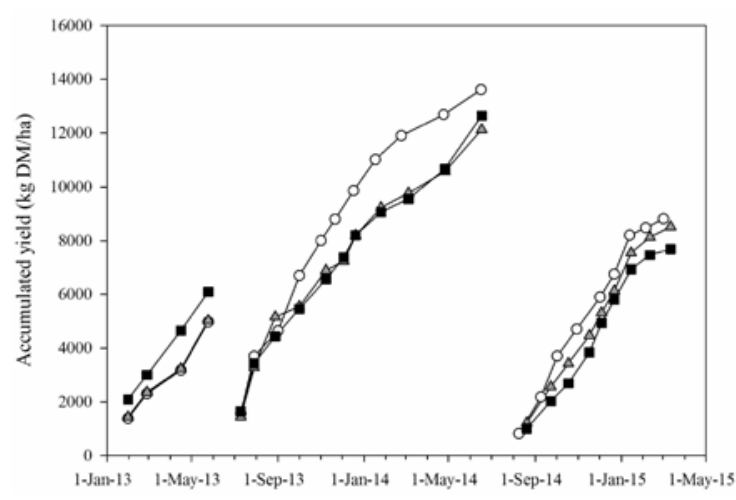

Figure 2 Accumulated yield (kg dry matter (DM)/ha) for the perennial ryegrass (RG-RG; squares), tall fescue managed as for ryegrass (TF-RG; triangles) and tall fescue managed as for tall fescue (TF-TF; open circles) strips across three growth periods (first grazing in January 2013 to June 2013, July 2013 to June 2014 and July 2014 to March 2015).

with RG (Minneé et al. 2010). While there was a $41 \%$ greater DM yield measured in the TF-TF strip compared with the RG-RG strip over the summer of Year 2, it is important to consider other plant parameters such as botanical composition, herbage quality and tiller density, to completely understand the effects on the swards under different grazing regimes.

\section{Short and long patches}

Patchiness of pastures, especially during periods of feed surplus, is well known but has seldom been studied (Milne et al. 1997). Figure 1 indicates 24 regrowth cycles for TF-TF over the course of the experiment and pasture height histograms for 16 of these were prepared from C-Dax data and visually inspected. Although the average post-grazing residual was not different between the three strips during the study at a mean of $1722 \pm 249$ (mean $\pm \mathrm{SD}$ ) $\mathrm{kg} \mathrm{DM} / \mathrm{ha}$, there were more long patches observed in TF-TF than TF-RG or RG-RG in 12 of the 16 charts. In some of the remaining cases the absence of such patches was attributable to mowing post-grazing. The differing herbage height profiles of the three strips are illustrated (Figure 3) for a series of three successive C-Dax pasture height measurements during a regrowth cycle in October 2013, after all three strips were grazed at the same time at the end of September (Figure 1). Figure 3 illustrates that 13 days post-grazing, the TFTF strip had approximately $60 \%$ frequency of C-Dax readings $>70 \mathrm{~mm}$ compared to $<25 \%$ on the other two strips. The greater frequency of C-Dax readings $>70 \mathrm{~mm}$ in the TF-TF strip persisted through the regrowth cycle as illustrated at 20 and 28 days post-grazing. Further research is required to understand the significance and best management of the patchiness observed in TF-TF. For example, patches could become problematic if they 
Day 13

Day 20

Day 28

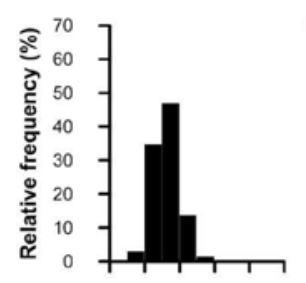

TF-TF
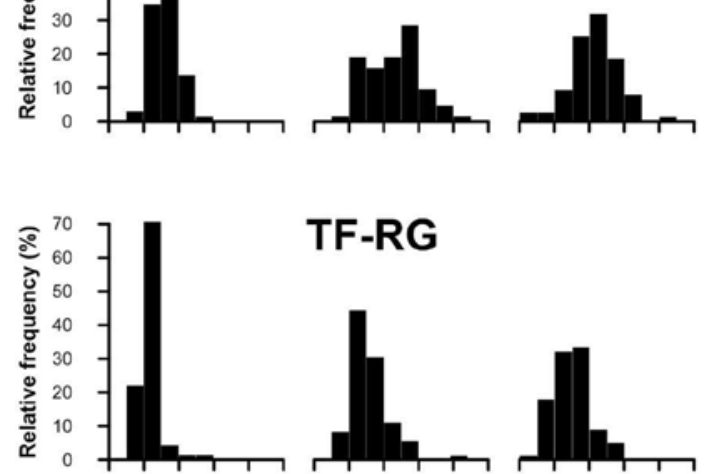

TF-RG
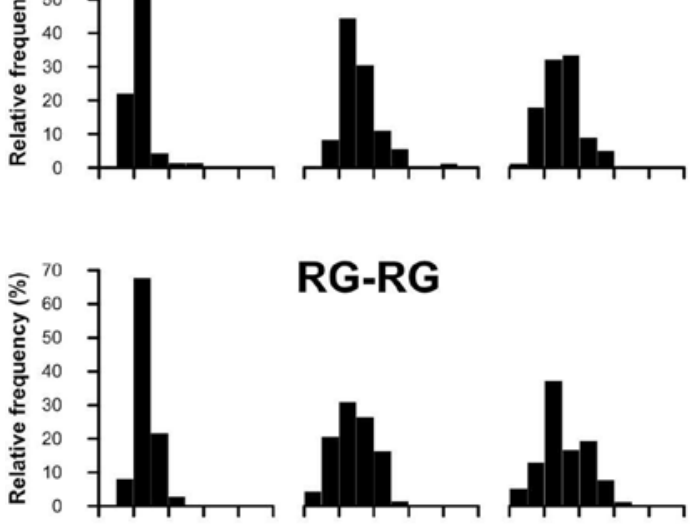

RG-RG

$40 \quad 6080100120140406080100120140406080100120140$ Pasture height $(\mathrm{mm})$

Figure 3 The frequency distribution of pasture height measured at 13,20 and 28 days post-grazing during a single regrowth cycle in October 2013 for perennial ryegrass (RG-RG), tall fescue managed as for ryegrass (TF-RG) and tall fescue managed as for tall fescue (TF-TF) strips. become permanent and mowing is required to eliminate them.

\begin{abstract}
Nutritive value
There was no treatment by height interaction for any of the nutritive value measures (Table 1). For RG-RG the $\mathrm{CP}$ in the long patches was higher than in the short patches, and SSS was lower in the long patches for TF$\mathrm{RG}$ compared to the short patches $(\mathrm{P}<0.05)$. The ME and SSS were generally higher in RG-RG compared with either of the TF strips. However, the differences in nutritive value between short and long patches and for all three treatments were small.
\end{abstract}

\section{Soil fertility and tiller density}

The tiller densities measured before commencing grazing treatments (23 January 2013) were on average higher in the RG-RG strip than the average of the two TF (TFRG, TF-TF) strips (3071 \pm 33 versus $1193 \pm 98$ tillers/ $\mathrm{m}^{2}$, respectively) $(\mathrm{P}<0.001)$. The tiller density of the two grass species at the end of the study (15 December 2015) was $2090 \pm 223$ versus $1576 \pm 129$ tillers $/ \mathrm{m}^{2}(\mathrm{P}<0.05)$, for the RG-RG and the average of the two TF (TF-RG, TF-TF) strips, respectively (Table 2). Visual observations suggested the initial tiller density was reduced by treading during an accidental grazing in the establishment phase, but the swards later recovered to a near normal visual appearance. The tiller density of the RG-RG strip at the start of the experiment can be regarded as optimal and the density of the two TF (TF-RG, TF-TF) strips suboptimal considering a tiller density of $>3000$ tillers/ $\mathrm{m}^{2}$ for RG-based pastures and $>2300$ tillers $/ \mathrm{m}^{2}$ for alternative grasses was indicative of a productive and persistent pasture comprising at least $70 \%$ sown species (Nie et al. 2004). However, tiller density in grass swards

Table 1 Parameters of nutritive value of herbage sampled from long and short patches for the period $30^{\text {th }}$ September 2013 $22^{\text {nd }}$ January 2014 for the perennial ryegrass (RG-RG), tall fescue managed as for ryegrass (TF-RG) and tall fescue managed as for tall fescue (TF-TF) strips.

\begin{tabular}{|c|c|c|c|c|c|c|c|c|c|c|}
\hline \multirow{2}{*}{$\begin{array}{l}\text { Nutritive } \\
\text { values }^{1}\end{array}$} & \multicolumn{2}{|c|}{ RG-RG } & \multicolumn{2}{|c|}{ TF-RG } & \multicolumn{2}{|c|}{ TF-TF } & \multirow[t]{2}{*}{ SEM } & \multirow[t]{2}{*}{ Treat $(\mathrm{T})$} & \multirow[t]{2}{*}{ Height (H) } & \multirow[t]{2}{*}{$\mathbf{T} \times \mathrm{H}$} \\
\hline & Long & Short & Long & Short & Long & Short & & & & \\
\hline $\mathrm{CP}$ & $19.3^{a}$ & $14.5^{\mathrm{b}}$ & $20.5^{a}$ & $17.4^{\mathrm{ab}}$ & $20.1^{\mathrm{a}}$ & $18.5^{a}$ & 1.23 & 0.128 & $<0.01$ & 0.469 \\
\hline DM & 20.9 & 20.0 & 22.3 & 20.2 & 20.1 & 21.5 & 1.97 & 0.923 & 0.750 & 0.672 \\
\hline NDF & 48.0 & 47.6 & 47.2 & 47.8 & 49.2 & 47.9 & 1.48 & 0.756 & 0.774 & 0.815 \\
\hline SSS & $16.3^{a b}$ & $16.7^{a}$ & $10.2^{d}$ & $13.4^{c}$ & $12.3^{\mathrm{cd}}$ & $13.7^{\mathrm{bc}}$ & 0.91 & $<0.001$ & $<0.05$ & 0.310 \\
\hline Lipid & 2.03 & 2.06 & 1.28 & 1.73 & 1.46 & 1.92 & 0.29 & 0.206 & 0.215 & 0.713 \\
\hline Ash & $8.60^{a}$ & $7.16^{c}$ & $8.60^{a}$ & $7.61^{\mathrm{bc}}$ & $8.33^{\mathrm{ab}}$ & $8.02^{\mathrm{abc}}$ & 0.29 & 0.581 & $<0.001$ & 0.183 \\
\hline OMD & $87.4^{\mathrm{a}}$ & $84.5^{\mathrm{ab}}$ & $79.6^{c}$ & $81.7^{\mathrm{bc}}$ & $80.2^{\mathrm{bc}}$ & $82.9^{a b c}$ & 1.55 & $<0.01$ & 0.618 & 0.164 \\
\hline ME & $12.5^{a}$ & $12.2^{\mathrm{ab}}$ & $11.7^{\mathrm{b}}$ & $11.9^{b}$ & $11.7^{b}$ & $11.9^{b}$ & 0.18 & $<0.01$ & 0.967 & 0.229 \\
\hline
\end{tabular}

abcMeans with different superscripts within variables are significantly different $(\mathrm{P}<0.05)$.

${ }^{1} \mathrm{CP}(\%$ dry matter (DM)), crude protein; DM (\%), dry matter; NDF (\% DM), neutral detergent fibre; SSS (\% DM), soluble sugars and starch; OMD (\% DM), organic matter digestibility; ME (MJ/kg DM), metabolisable energy. 
is a mechanism for LAI adjustment by which swards optimise light interception in response to grazing regime, fluctuating seasonally (Matthew et al. 2013), so it is difficult to infer the productive status of the pasture from tiller density data alone.

There was a difference in final tiller density when comparing the RG-RG strip with TF-RG $(\mathrm{P}<0.05)$, however, this was not significantly different when comparing RG-RG with TF-TF or TF-RG with TFTF (Table 2). Additional information is needed to determine when a low tiller density denotes lack of persistence. This issue was addressed by comparing the LAI of the three strips. Tiller density data were used in conjunction with pseudostem-leaf dissection data and specific leaf area data to generate a LAI of the sown grass species in the three strips. There was a clear statistical separation with the strips ranking TF-TF $>$ TF-RG $>$ RG-RG, with a range of 2.25-0.90 (Table 2). It is generally accepted that a LAI of 3-4 is required to intercept $95 \%$ of incident light and these differences between species emphasise the importance of physiological or morphological characteristics in influencing regrowth behaviour (Tavakoli 1993).

Tiller density was not significantly different between TF-TF and TF-RG, however, the yield and LAI of the sown species were greater in TF-TF than in TF-RG $(\mathrm{P}<0.05)$. While the point cannot be proven from this unreplicated experiment alone, a fully replicated plot trial in the same paddock with mowing treatments to simulate various grazing regimes produced a similar response pattern across treatments (Kaufononga 2015). This indicates a sensitivity of TF to different grazing regimes and the importance of managing the sward according to the specific growth habits of TF to maximise productivity and persistence (Donaghy et al. 2008). Sown species LAI and yield may therefore be better measures of persistence and productivity than tiller density alone (Matthew et al. 2013).

Soil fertility as assessed by Olsen P did not differ between strips ( $\mathrm{P}=0.888$ ), and averaged $28.4 \mathrm{mg} / \mathrm{kg}$ across the experiment site. However, the perceived fertility gradient was confirmed, with Olsen P declining at $0.130 \mathrm{mg} / \mathrm{kg} / \mathrm{m}$ with distance away from the farm race $(\mathrm{P}=0.002)$. Gradients for $\mathrm{pH}, \mathrm{K}, \mathrm{Ca}, \mathrm{Mg}$ and cation exchange capacity data were not significantly different from zero (data not shown). Tiller density, LAI of sown species, sown species yield and total yield sampled along the soil Olsen $\mathrm{P}$ gradient all positively correlated with Olsen P, confirming that soil fertility is a major factor to be considered in pasture production and persistence (Mackay et al. 2011) (Table 2). The Olsen P response coefficients (Table 2) were tested statistically for differences between RG-RG, TF-RG and TF-TF strips, and none was found.

Herbage nutritive value parameters and leaf N\% did not show any response to Olsen P. For example, herbage ME, averaged across the three strips was 10.3 $\mathrm{MJ} / \mathrm{kg}$ (SE 0.34) at transect 4 (furthest from farm race; Olsen $\mathrm{P}=18.3$ ) and $10.7 \mathrm{MJ} / \mathrm{kg}$ (SE 0.34) at transect 1 (nearest farm race; Olsen $\mathrm{P}=37.3$ ). Corresponding values for herbage N\% were 2.43 (SE 0.31 ) and 2.57 (SE 0.31), respectively. The increase in herbage mass of $255 \mathrm{~kg}$ DM per unit increase in Olsen P (Table 2) along the fertility gradient without significant change in herbage $\mathrm{N} \%$, indicates that $\mathrm{N}$ supply also increased along the fertility gradient towards the race, and that plant growth was such that $\mathrm{N}$ in plant tissue was diluted to a constant final N\% (Lemaire 1997).

\section{Botanical composition}

There was no effect of treatment on the proportion of sown species, weeds or dead herbage in the sward at the end of the experiment. The proportion of clover in the sward was greater in the RG-RG strip compared with the TF-RG and TF-TF strips $(\mathrm{P}<0.05)$. Previous studies have reported that TF often has a greater proportion of legume compared with RG due to its slow establishment and more bare ground (Tozer et al. 2011), but that was not the case in the current study.

There was a greater ingression of weed grasses in the

Table 2 Tiller density $\left(/ \mathrm{m}^{2}\right)$, sown species leaf area index (LAI), sown species yield and total yield (kg dry matter (DM)/ha) from final tiller density measures $\left(14^{\text {th }}\right.$ December 2015$)$ for the perennial ryegrass (RG-RG), tall fescue managed as for ryegrass (TF-RG) and tall fescue managed as for tall fescue (TF-TF) strips. Olsen P coefficients with their SE in parentheses are presented from multiple linear regression analyses undertaken to determine the effect of Olsen $\mathrm{P}$ at four transects moving down the paddock $(55,100,145$, and $190 \mathrm{~m}$; farm race at $0 \mathrm{~m})$ on aforementioned factors.

\begin{tabular}{lccccc}
\hline Plant characteristic & RG-RG & TF-RG & TF-TF & SEM & Olsen P coefficient \\
\hline Tiller density/m² & $2090^{\mathrm{a}}$ & $1429^{\mathrm{b}}$ & $1722^{\mathrm{ab}}$ & 196 & $36.0(4.46)$ \\
Sown species LAI & $0.90^{\mathrm{c}}$ & $1.56^{\mathrm{b}}$ & $2.25^{\mathrm{a}}$ & 0.20 & $0.04(0.01)$ \\
Sown species yield, kg DM/ha & 1114 & 1167 & 1603 & 166 & $34.7(4.16)$ \\
Total yield, kg DM/ha & $3626^{\mathrm{b}}$ & $3826^{\mathrm{b}}$ & $4581^{\mathrm{a}}$ & 255 & $60.9(6.35)$ \\
\hline
\end{tabular}

${ }^{a b c}$ Means with different superscripts within variables are significantly different $(P<0.05)$.

Olsen $\mathrm{P}$ coefficients are significantly different at the $5 \%$ confidence level. Standard errors for Olsen $\mathrm{P}$ coefficients are presented in brackets. 
TF-RG strip compared with either the RG-RG or the TF-TF strips $(\mathrm{P}<0.05)$, indicating a lack of competitive ability against ingression of weed grasses by TF when managed the same as RG. In agreement with Bell (1985), RG had a superior competitive ability against grass weeds compared with TF when under the same management (164 versus $302 \mathrm{~g}$ other grass $/ \mathrm{kg}$ DM for RG-RG verses TF-RG, respectively).

\section{Conclusion}

Results from this study indicate a sensitivity of TF to different grazing regimes and highlight the importance of managing TF pastures according to the specific growth habits of TF to maximise productivity and persistence. The disadvantage of grazing TF under a RG grazing regime was expressed through decreased DM yield and sown species LAI, and increased grass weed ingression. However, while longer grazing rotations allowing emergence of maximum live leaves/tiller appear to maximise DM yield, plant energy reserves and root mass (Donaghy et al. 2008), attaining these under field conditions whilst trying to maintain intake of grazing cows, is likely to continue to prove elusive. Future studies may benefit from using sown species LAI in addition to tiller density as measures to indicate persistence. Additionally, while grazing management is important to optimise pasture productivity and persistence, it appears that spatial differences in soil nutrients can also have an effect on pasture productivity and persistence.

\section{ACKNOWLEDGEMENTS}

This work was funded by Pastoral 21, a joint venture between DairyNZ, Fonterra, Dairy Companies Association of New Zealand, Beef + Lamb New Zealand and the Ministry of Business Innovation and Employment. Particular thanks to Massey and AgResearch staff involved in the setting up and running of this study.

Table 3 The proportions ( $\mathrm{g} / \mathrm{kg}$ dry matter (DM)) of sown species, other grasses, clover, weeds and dead herbage at end of the experiment $\left(14^{\text {th }}\right.$ December 2015) for the perennial ryegrass (RG-RG), tall fescue managed as for ryegrass (TF-RG) and tall fescue managed as for tall fescue (TF-TF) strips.

\begin{tabular}{lcccc}
\hline Item & RG-RG & TF-RG & TF-TF & SEM \\
\hline Sown species & 212 & 206 & 238 & 16.5 \\
Other grasses & $164^{\mathrm{b}}$ & $302^{\mathrm{a}}$ & $207^{\mathrm{b}}$ & 29.5 \\
Clover & $217^{\mathrm{a}}$ & $111^{\mathrm{b}}$ & $140^{\mathrm{b}}$ & 22.6 \\
Weeds & 56.3 & 30.0 & 43.2 & 12.4 \\
Dead & 140 & 145 & 133 & 13.7 \\
\hline
\end{tabular}

a, bMeans with different superscripts within variables are significantly different $(P<0.05)$.

\section{REFERENCES}

Allo, A.V.; Southon, T. 1967. Experiences with tall fescue. Proceedings of the New Zealand Grassland Association 29: 128-134.

Bell, C.C. 1985. Effect of defoliation frequency on simulated swards of ryegrass, tall fescue, and a 50/50 mixture of the two species. New Zealand Journal of Agricultural Research 28: 307-312.

Clark, C.E.F.; Clark, D.A.; Waugh, C.D.; Roach, C.G.; Glassey, C.B.; Woodward, S.L.; Minneé, E.M.K.; Woodfield, D.R. 2010. Systems to increase grazeable forage production in the Waikato: a progress report on the tall fescue and perennial ryegrass components of these systems. Proceedings of the New Zealand Grassland Association 72: 49-54.

DairyNZ 2008. 1-15 Using the rising plate meter (RPM) (DairyNZ Farmfact). Hamilton, New Zealand: Dairy New Zealand.

Donaghy, D.J.; Turner, L.R.; Adamczewski, K.A. 2008. Effect of defoliation management on water-soluble carbohydrate energy reserves, dry matter yields, and herbage quality of tall fescue. Agronomy Journal 100: 122-127.

Easton, H.S.; Pennell, C.G. 1993. Breeding tall fescue for establishment vigour. Proceedings of the New Zealand Grassland Association 55: 151-154.

Easton, H.S.; Lee, C.K. Fitzgerald, R.D. 1994. Tall fescue in Australia and New Zealand. New Zealand Journal of Agricultural Research 37: 405-417.

Fulkerson, W.J.; Donaghy D.J. 2001. Plant-soluble carbohydrate reserves and senescence - key criteria for developing an effective grazing management system for ryegrass-based pastures: a review. Australian Journal of Experimental Agriculture 41: 261-275.

Hirata, M. 2000. Quantifying spatial heterogeneity in herbage mass and consumption in pastures. Journal of Range Management 53: 315-321.

Kaufononga, S. 2015. Comparative response of tall fescue (Lolium arundinacea Schreb.) and perennial ryegrass (Lolium perenne L.) swards to variation in defoliation interval and height. Masters thesis. Massey University.

Kemp, P.D.; Matthew, C.; Lucas, R.J. 2002. Pasture species and cultivars. pp. 83-99 In: New Zealand pasture and crop science. Eds. Hodgson, J.G.; White, J. Oxford University Press, Auckland.

Kemp, P.D.; Tavakoli, H.; Hodgson, J. 2001. Physiological and morphological responses of tall fescue and perennial ryegrass to leaf defoliation. $10^{\text {th }}$ Australian Agronomy Conference, Hobart, Tasmania. http://www.regional.org.au/au/asa/2001/2/d/kemp.htm

Kerrisk, J.J.; Thomson, N.A. 1990. Effect of intensity and frequency of defoliation on growth of ryegrass, tall fescue and phalaris. Proceedings of the New Zealand Grassland Association 51: 135-138. 
King, W.M.; Rennie, G.M.; Dalley, D.E.; Dynes, R.A.; Upsdell, M.P. 2010. Pasture mass estimation by the C-DAX Pasture meter: Regional calibrations for New Zealand. pp. 233-238. In: Proceedings of the 4th Australasian Dairy Science Symposium.

Lazenby, A.; Lovett, J.V. 1975. Growth of pasture species on the Northern Tablelands of New South Wales. Australian Journal of Agricultural Research 26: 269-280.

Lemaire, G. 1997. Diagnosis of the nitrogen status in crops. Ed. Berlin, Germany: Springer-Verlag.

Litherland, A.J.; Woodward, S.J.R.; Stevens, D.R.; McDougal, D.B.; Boom, C.J.; Knight, T.L.; Lambert, M.G. 2002. Seasonal variations in pasture quality on New Zealand sheep and beef farms. Proceedings of the New Zealand Society of Animal Production 62: 138-142.

Mackay, A.D.; Gillingham, A.; Smith, C.; Budding, P.; Phillips, P.; Clarke-Hill, W.; Johnston, P. 2011. Effects of soil physical condition, and phosphorus and nitrogen availability on pasture persistence. Pasture Persistence Symposium. Grassland Research and Practice Series 15: 85-92.

Matthew, C.; Agnusdei, M.G.; Assuero, S.G.; Sbrissia, A.F.; Scheneiter, O.; Da Silva, S.C. 2013. State of knowledge in tiller dynamics. pp. 1041-1044. In: Proceedings of the $22^{\text {nd }}$ International Grassland Congress.

McCallum, D.A.; Thomson, N.A.; Thom, E.R. 1992. The place of tall fescue in intensive dairying. Proceedings of the Ruakura Farmer's Conference 44: 93-97.
Milne, G.D.; Shaw, R.; Powell, R.; Pirie, B.; Pirie, J. 1997. Tall fescue use on dairy farms. Proceedings of the New Zealand Grassland Association 59: 163168.

Minneé, E.M.K.; Knight, T.L.; Sutherland, B.L.; Blaming, J.B.; Fletcher, L.R.; Clark, D.A. 2010. Herbage production from perennial ryegrass and tall fescue pastures under irrigation in the Canterbury and Waikato regions of New Zealand. Proceedings of the New Zealand Grassland Association 72: 185190.

Nie, Z.N.; Chapman, D.F.; Tharmaraj, J.; Clements, R. 2004. Effects of pasture species mixture management and environment on the productivity and persistence of dairy pasture in south-west Victoria. 2. Plant population density and persistence. Australian Journal of Agricultural Research 55: 637-643.

Rollo, M.D.; Sheath, G.W.; Slay, M.W.A.; Knight, T.L.; Judd, T.G.; Thomson, N.A. 1998. Tall fescue and chicory for increased summer forage production. Proceedings of the New Zealand Grassland Association 60: 249-253.

Tavakoli, H. 1993. Physiological and morphological responses of tall fescue (Festuca arundinacea Schreb.) and perennial ryegrass (Lolium perenne L.) to defoliation. $\mathrm{PhD}$ thesis. Massey University.

Tozer, K.N.; Bourdot, G.W.; Edwards, G.R. 2011. What factors lead to poor pasture persistence and weed ingress? Proceedings of the New Zealand Grassland Association 15: 129-138.

Valentine, J.F. 2000. Grazing Management ( $\left.2^{\text {nd }} e d.\right)$. San Diego, California: London, Academic. 